Brit. J. industr. Med., 1961, 18, 7.

\title{
OBSERVATIONS ON THE URINARY PROTEIN OF MEN EXPOSED TO CADMIUM DUST AND FUME
}

\author{
BY \\ J. C. SMITH*, AGNES R. WELLS, and J. E. KENCH $\dagger$ \\ From the Nuffield Department of Occupational Health and Department of Chemical Pathology, \\ University of Manchester
}

(RECEIVED FOR PUBliCATION FEBRUARY 8, 1960)

\begin{abstract}
Urinary protein from five cadmium workers has been examined, two men exposed to cadmium dust and three to cadmium fume. No difference was discernible between the two groups in regard to the quantity of protein excreted (10 to 36 times the average normal) or to the chemical composition and molecular weight of the protein. Cadmium urinary protein exhibits a complex electrophoretic pattern on paper, with five components. These have mobilities similar to the five main fractions of serum. All their molecular weights, however, are in the range 20 to 30,000 . Filter paper electrophoresis showed a preponderance of globulins, especially $\alpha_{2}$, over albumin. On column electrophoresis, however, a relatively higher proportion of albumin appeared, due probably to a change of mobility of a heat incoagulable protein, which constituted 20 to $25 \%$ of the whole. The heat incoagulable protein had a high content of glycine, serine, hexose, methylpentose, and sialic acid. Electrophoretic fractions 1 and 2 of the urinary protein were similarly rich in glycine, serine, hexose, methylpentose, and sialic acid, possibly due to presence of heat incoagulable protein. The presence of two components in fraction 1 became evident from ultracentrifugal studies. Plasma proteins could be demonstrated immunologically in the urine, but the relative proportion present could not be assessed. Urinary proteins associated with cadmium absorption include components of low molecular weight and high carbohydrate content similar to those which have been observed in normal urine. The distinctive feature of the proteinuria appears to be the presence of a low molecular urinary albumin, the origin of which is the subject of further study.
\end{abstract}

Small quantities of protein can be recovered from normal urine (McGarry, Sehon, and Rose, 1955; Webb, Rose, and Sehon, 1958a). The occurrence of abnormally increased proteinuria in men chronically exposed in industry to cadmium oxide dust was first described by Friberg (1950). Similar findings were reported by Baader (1951) and Smith, Kench, and Lane (1955). A high incidence of proteinuria in men exposed to cadmium fume has also been observed (Bonnell, 1955; Smith and Kench, 1957).

The urinary protein associated with inhalation of cadmium oxide dust or fume is of special interest in that, although it has been shown to comprise several components electrophoretically, the molecular weight was consistently in the range $20-30,000$

\footnotetext{
* Present Address: Department of Biochemistry, University of Pittsburgh School of Medicine, Pittsburgh, Pennsylvania, U.S.A.

+ Present Address: Department of Chemical Pathology, University of Cape Town Medical School, Observatory, Cape, South Africa.
}

(Friberg, 1950; Kekwick, 1955). This feature of the cadmium urinary protein encouraged us to consider that this protein might be a specific product of cadmium poisoning, a consequence of a metabolic disturbance induced by cadmium. Accordingly this possibility has been explored and the present paper describes electrophoretic behaviour and chemical analysis of the various components of the cadmium urinary protein.

Whilst our investigations were proceeding, it was shown by Webb et al. $(1958 \mathrm{a}, \mathrm{b})$ that globulins occurring in traces in normal urine are of low molecular weight and, as will be clear from our present report, are also similar in other ways to the protein excreted in the urine of cadmium workers.

\section{Materials and Methods}

The five men chosen for study were all excreting protein in quantities greater than $1 \mathrm{~g}$./1. Two (D1 and 
D2) were engaged in the manufacture of alkaline accumulators and were exposed to cadmium oxide dust. The other three (F1, F2, and F3) were employed in the production of cadmium-copper alloy; $F 1$ and $F 2$ at one foundry and F3 at a second. D1 and F1 were excreting large quantities of cadmium and D2 and F2 relatively small quantities. F3 was the only worker at Foundry II excreting protein in amounts above the chosen minimum and his cadmium excretion was intermediate between these two pairs.

Urinary specimens were collected at mid-morning, directly into wide-necked pyrex bottles of $400 \mathrm{ml}$. capacity, previously cleaned and sterilized by heat. Each bottle contained a small crystal of thymol to minimize bacterial growth during transit to the laboratory. Examination of urinary specimens from the foundry workers could begin within three to four hours of collection, whilst those from the more distant alkaline accumulator factory were received during the following day.

The following investigations were then made on the urine:

Creatinine.-Creatinine concentration was determined by the alkaline picrate and Lloyd's reagent method of Owen, Iggo, Scandrett, and Stewart (1954).

Urinary Cadmium.-The concentration of cadmium in the urine was determined by the dithizone (diphenylthiocarbazone) method of Smith et al. (1955).

Studies on the Protein.-Total protein concentration was measured by a modification of the biuret method of Hiller, McIntosh, and Van Slyke (1927).

Preparation fOR ANAlysis.-Diffusible substances such as urea, salts, and much pigment were removed by dialysing the urine in cellophane sacs overnight against running tap water and subsequently against distilled water for three to four hours. The residue was freezedried and the protein was then obtained as a light, watersoluble powder, always associated with a certain amount of brownish pigment, assumed to be urochrome. Attempts to remove this pigment by prolonged dialysis or by precipitating the protein from solution with cold organic solvents were unsuccessful.

Freeze-dried proteins were prepared in a similar manner from the urine of two persons with chronic nephritis but with no known exposure to cadmium, from normal serum, and from serum of a cadmium worker (D1).

Protein-Bound Hexose.-This was measured according to the orcinol (5-methyl resorcinol) procedure of Weimer and Moshin (1953). A $2: 1$ mixture of galactose and mannose was employed as a standard, this ratio approximating to the proportion of hexose found by chromatography.

Protein-Bound Fucose.-The cystine method of Dische and Shettles (1948), with a fucose standard, was followed.

Protein-Bound Sialic Acid.-This was determined by the diphenylamine method of Ayala, Moore, and Hess
(1951). The standard employed was $a_{1}$-glycoprotein (orosomucoid) containing $11 \cdot 2 \%$ sialic acid (kindly supplied by Dr. D. S. Jackson).

Electrophoretic Separation.-The electrophoretic behaviour of the protein was examined on paper by the ridgepole technique of Durrum (1950), the protein fractions being located with azocarmine B (Plückthun and Götting, 1951) and the profile derived with an EEL "scanner" using a blue filter (maximal absorption $460 \mathrm{~m} \mu$ ).

The proteins were also examined by zone electrophoresis on vertical acetyl cellulose columns (Flodin and Porath, 1954; Campbell and Stone, 1956), in a borate-phosphate buffer medium $\left(0.0115 \mathrm{M}, \mathrm{Na}_{2} \mathrm{~B}_{4} \mathrm{O}_{7}\right.$, $\left.0.0155 \mathrm{M}, \mathrm{NaH}_{2} \mathrm{PO}_{4}, \mathrm{I}=0.05, p \mathrm{H} 8.6\right) ; 150 \mathrm{mg}$. freezedried protein dissolved in buffer and applied to the column was well separated into its component fractions by a potential difference of $220 \mathrm{v}$. applied for 44 hours. Satisfactory results were achieved by application of higher gradients up to $270 \mathrm{v}$. for somewhat shorter periods of time. Following electrophoresis, the protein fractions were eluted from the column by buffer and collected in $5 \mathrm{ml}$. fractions, the concentrations of protein being assessed by the optical density at $280 \mathrm{~m} \mu$ measured in a Unicam Spectrophotometer S.P. 500.

Those portions of each electrophoretic component having peak absorption values were pooled and the resultant solution checked for homogeneity by paper electrophoresis, before individual preparation for analysis by dialysis and freeze drying.

A few separations were carried out in a similar manner in barbiturate buffer, $\mathrm{I}=0.075, p \mathrm{H} \mathrm{8.6}$.

Amino Acid Composition.-Each freeze-dried component separated by zone electrophoresis was hydrolysed with $6 \mathrm{~N} . \mathrm{HCl}$ according to Block (1951). The derived amino acids were separated by the two-dimensional paper chromatographic procedure described by Clarkson and Kench (1956), with methanol : water : pyridine (80:20:4 by vol.) and ethyl methyl ketone : tert-butanol : water : diethylamine (40:40:20:4 by vol.).

The solution of amino acids in $10 \%$ isopropanol water was applied directly to the paper.

Carbohydrate Content.-The components were hydrolysed with $\mathrm{N}_{2} \mathrm{H}_{2} \mathrm{SO}_{4}$ in sealed tubes (Consden and Stanier, 1952). Descending chromatography with ethyl acetate : pyridine : water (40:20:40 by vol.) (Jermyn and Isherwood, 1949) was employed and the sugars were detected by spraying with aniline phthalate (Partridge, 1948). The sugars were measured by determination of the areas of spots (Fisher, Parsons, and Holmes, 1949).

Ultracentrifuge Measurements.-Samples of the freeze-dried proteins were dissolved in phosphate-sodium chloride buffer, $p \mathrm{H} \mathbf{8} .0$, total ionic strength 0.35 $\left(\mathrm{KHPO}_{4}, 0.0044 \mathrm{M}, \mathrm{Na}_{2} \mathrm{HPO}_{4}, 0.0652 \mathrm{M}, \mathrm{NaCl}\right.$ 0.15 M) and dialysed in cellophane tubes for about 24 hours at $4^{\circ} \mathrm{C}$. against a large volume of the same buffer. The refractive increment due to protein in the dialysed solutions was determined with a dipping refractometer $(\lambda=546 \mathrm{~m} \mu)$ and the solutions diluted to $1.0 \mathrm{~g}$. 
TABLE 1

CONCENTRATIONS OF CADMIUM AND PROTEIN IN THE URINE OF FIVE MEN EXPOSED TO CADMIUM DUST AND FUME

\begin{tabular}{c|c|c|c}
\hline Workman & $\begin{array}{c}\text { Exposure } \\
\text { (years) }\end{array}$ & $\begin{array}{c}\text { Cadmium } \\
(\mu \mathrm{g} . / 1 .)\end{array}$ & $\begin{array}{c}\text { Protein } \\
(\mathbf{g} . / 1 .)\end{array}$ \\
\hline D1 & 14 & 640 & $3 \cdot 2$ \\
D2 & 25 & 75 & $1 \cdot 0$ \\
F1 & 32 & 310 & $3 \cdot 1$ \\
F2 & 37 & 50 & $1 \cdot 2$ \\
F3 & 22 & 100 & $2 \cdot 3$ \\
\hline
\end{tabular}

The cadmium values have been corrected to those for a standard urine containing $1.00 \mathrm{~g} . / 1$. creatinine by the method of Smith and Kench (1957). The protein values are approximate means without correction for urinary concentration.

The concentration of cadmium in normal human urine is $<25 \mu \mathrm{g}$./1.

protein $/ 100 \mathrm{ml}$. The solutions were then examined in the Svedberg oil-turbine ultracentrifuge in a $12 \mathrm{~mm}$. cell at approximately $250,000 \mathrm{G}$. Optical observations by the diagonal schlieren method (Philpot, 1938) were photographically recorded on Ilford half-tone panchromatic plates, using a high pressure mercury arc as a light source from which monochromatic light $(\lambda=546 \mathrm{~m} \mu)$ was isolated by a suitable filter. Distances on the plates were determined with a measuring microscope reading to $0.001 \mathrm{~mm}$. and sedimentation coefficients were computed by the method of Cecil and Ogston (1948).

IMMUNOLOGY.-This was carried out by the tube precipitin method of Oakley and Fulthorpe (1953) using rabbit antiserum prepared against proteins of whole normal human serum.

IMMUNOELECTROPHORESIS.-About $0.05 \mathrm{ml}$. of a $1 \%(w / v)$ solution of protein was subjected to electrophoresis in a $3 \mathrm{~mm}$. deep plate of agar poured from a $2 \%(w / v)$ agar solution in glycine- $\mathrm{NaCl}$ buffer, $p \mathrm{H} 8.4$ (glycine $0.05 \mathrm{M}, \mathrm{NaCl} 0.05 \mathrm{M}, \mathrm{NaOH} 0.0025 \mathrm{M}$, trisodium citrate $0.002 \mathrm{M}$ ). The electrophoresis was carried out for a period of 24 hours at $4^{\circ} \mathrm{C}$. with a current density of $2 \mathrm{~m} \AA$ per cm. width of gel. Rabbit antiserum to whole human plasma was then pipetted into a channel in the gel parallel to the direction of electrophoresis, and

the precipitin bands were allowed to develop at $4^{\circ} \mathrm{C}$. Photographs of the bands were taken at intervals of seven days for four weeks.

Viscosity.-This was measured with an Ostwald viscometer suspended in a water bath at $25^{\circ} \mathrm{C}$.

\section{Results}

The concentrations of cadmium and protein in the urine from the five men studied are presented in Table 1. Variation from these values was slight. The greatest protein excretion found was $4 \cdot 2 \mathrm{~g}$./1. in workman D1 accompanied by a cadmium level of $670 \mu \mathrm{g} . / \mathrm{l}$. Although of the five men D1 had the shortest period of exposure, he had for a number of years been subjected to abnormally high concentrations of cadmium dust.

Urinary proteins from all five men exhibited electrophoretic behaviour on paper, representative of which is the profile from D1 (Fig. 1a). Five bands were obtained, as with serum proteins under these conditions. The bands were of closely similar electrophoretic mobilities but present in proportions differing from those found in serum. Most noteworthy was the preponderance of globulins, particularly of a component migrating slightly more slowly than $\alpha_{2}$-globulin. The pattern for each man was subject to only minor variation throughout the period of study. No changes in these patterns nor in other characteristics of the protein were manifest in urinary specimens allowed to stand in the cold for up to 10 days. The urine of a number of the workmen, showing only a trace of proteinuria, gave electrophoretic patterns with no component of mobility comparable with that of albumin. This is in distinction to the trace proteinurias which are rich in albumin in our control group not exposed to cadmium.

The urinary proteins from all five subjects gave

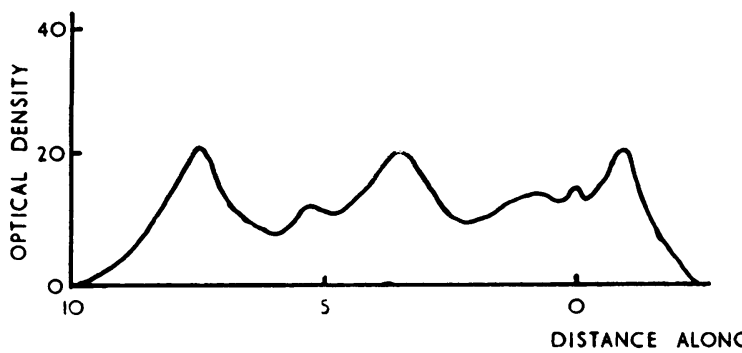

[0]

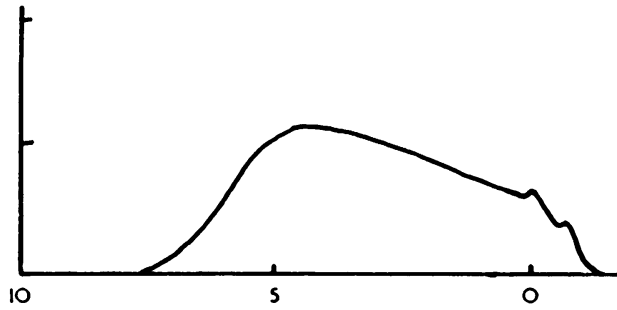

[b]

FIG. 1.-Electrophoresis on paper of urinary proteins from the cadmium worker D1: (a) Pattern of complete mixture of urinary proteins, (b) Heat incoagulable proteins (H1P) separated from the mixture.

The preparation was applied at 0 . Separation was carried out in barbiturate buffer $\mathbf{I} .0 .075$, pH 8.6, with voltage gradient $3 \cdot 2$ volts/cm. and current density 0.3-0.4 amps/cm., and duration or runs 18 hours. Proteins were stained with azocarmine $B$ and the profile derived with an EEL "scanner" using a blue filter (absorption maximum $460 \mathrm{~m}(\ell$ ). Optical density is expressed as readings of the instrument. 

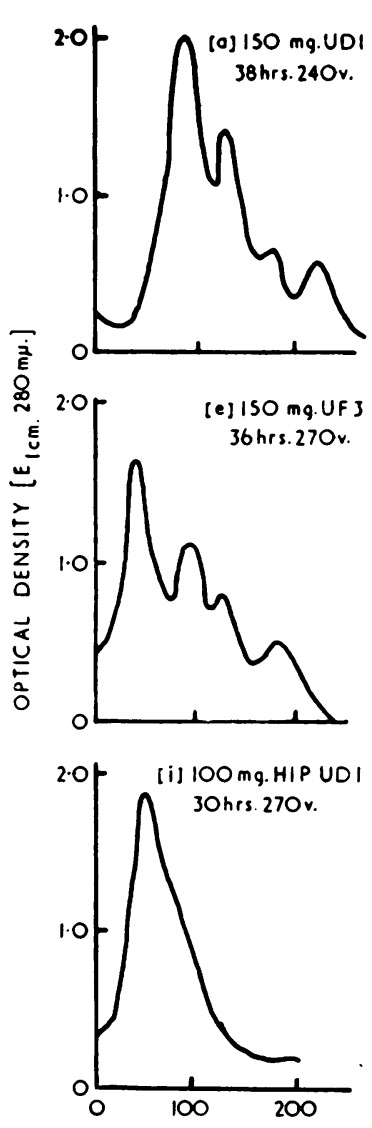
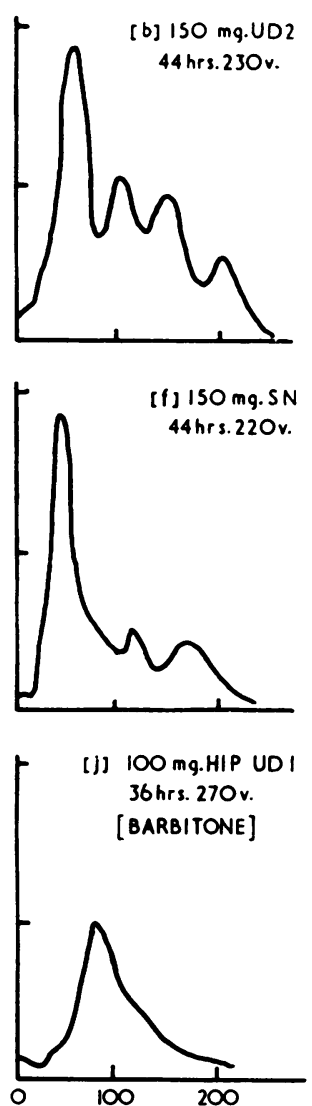
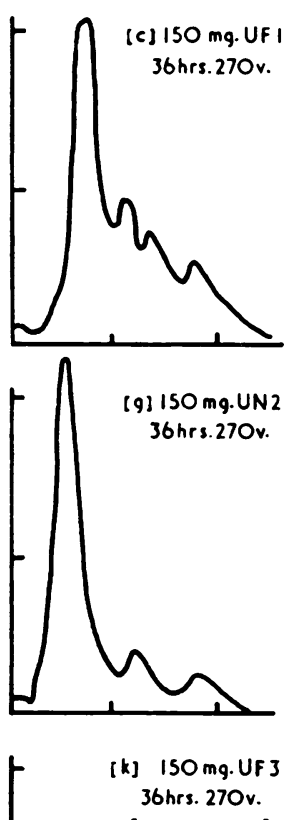

[BARBITONE]

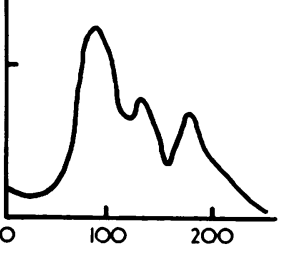

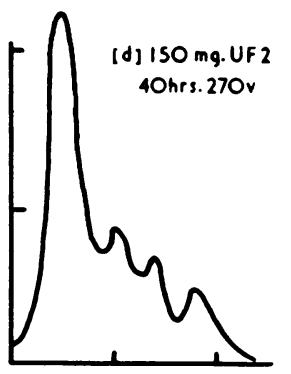

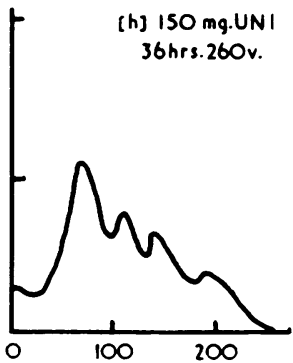

VOLUME ELUATE [ml.]

FIG. 2.-Zone electrophoresis of serum and urinary proteins on vertical acetyl cellulose columns. Duration of run in hours, potential gradient in volts; $\mathbf{S N}=$ normal serum proteins; HIP = heat incoagulable protein; $(\mathrm{g})$ and $(\mathrm{h})$ are nephritic patients.

Specimens a-i were examined in borate-phosphate medium; $j$ and $k$ in barbiturate buffer.

Ordinates throughout are optical density measurements at $280 \mathrm{~m} / \mathrm{l}$ of $5 \mathrm{ml}$. fractions of the eluate from the column; abscissae represent the total volumes of protein solution eluted.

similar patterns when examined by acetyl cellulose column electrophoresis as shown in Fig. 2a-e. Four components only were seen in each case and were enumerated 1-4, having electrophoretic mobilities comparable with serum albumin, $\alpha_{2^{-}}, \beta-$, and $\gamma$-globulins. The second fastest fraction of urinary protein appeared to travel with the tail of the first, whilst, under the same conditions, the $\alpha$-globulins were not separable from normal serum proteins (Fig. 2f) nor from the proteins of one of the nephritic urines (Fig. 2g). The urinary protein from the second nephritic patient exhibited four components (Fig. 2h).

A proportion of the cadmium urinary protein was heat incoagulable, varying when measured as biuret, from $20 \%$ in F2 to $25 \%$ in D1. This heat incoagulable protein (HIP) moved as a broad band on paper electrophoresis in the region normally occupied by the $\alpha_{2}$-globulins (Fig. 1b). Column electrophoresis, however, showed it to be a single asymmetric peak with a mobility slightly greater than that of albumin (Fig. 2i). This increase in mobility in the presence of the borate in the buffer was presumably due to the high carbohydrate content of this protein. The replacement of boratephosphate with barbitone buffer reduced the mobility (Fig. 2j) without giving a pattern comparable to that on paper. The urinary protein as a whole also retained the general form shown in borate-phosphate buffer when examined in barbitone buffer (Fig. 2k) but the albumin peak was retarded. Addition of HIP to the total urinary protein resulted, 
in both buffers on columns of acetyl cellulose, in augmentation of the albumin peak only.

Protein-bound Carbohydrate.-Preliminary experiments showed that the cadmium urinary proteins contained a considerable amount of bound carbohydrate. The nature of this carbohydrate was investigated by paper chromatography of hydrolysates of total urinary protein. By the use of alternative solvent systems all the sugars were shown to be uncontaminated. The results are presented in Table 2.

The distribution of the carbohydrate among the electrophoretic components isolated from the column was investigated by chemical methods. Values for total hexose attached to total protein and to various components are given in Table 3 expressed as protein determined by biuret. Similarly, data for sialic acid bound to the proteins appear in Table 4, and for methylpentoses in Table 5.

Amino Acid Composition.-A total of 13 amino acids was determined by chromatography. For purposes of comparison the eight most accurately measurable were selected and each value expressed as a percentage of the total eight for each component analysed. The amino acids selected were alanine, arginine, aspartic acid, glutamic acid, glycine, histidine, lysine and serine. The results are shown in Table 6.

Sedimentation.-The total urinary proteins of patients D1 and F3 were examined in the ultracentrifuge. Each of these displayed a single, almost symmetrical peak, and the respective sedimentation coefficients were $1.96 \mathrm{~S}$ and $1.99 \mathrm{~S}\left(\mathrm{~S}_{20}, \mathrm{w}\right.$ at $1 \%$ protein). The degree of boundary spreading observed was consistent with the low sedimentation coefficient which indicates a molecular weight of the order of 20,000-30,000. The corresponding coefficient of the nephritic urinary protein UN1, was 4.04 which is close to the value for human serum albumin (Kekwick, 1958). These values are in good agreement with previous measurements on similar materials (Kekwick, 1955).

The albumin fraction separated electrophoretically on acetyl cellulose from the urinary protein of patient D1 resolved into two components when

TABLE 2

RELATIVE PROPORTIONS OF MONOSACCHARIDES BOUND TO CADMIUM URINARY PROTEIN, AND TO NEPHRITIC URINARY AND NORMAL SERUM PROTEINS

\begin{tabular}{|c|c|c|c|c|c|c|}
\hline Nature of Protein & No. of Analyses & Galactose & Glucose & Mannose & Fucose & Ribose \\
\hline $\begin{array}{l}\text { UD1 } \\
\text { UD2 } \\
\text { UF1 } \\
\text { UF2 } \\
\text { UF3 } \\
\text { HIP } \\
\text { UN1 } \\
\text { UN2 } \\
\text { SN } \\
\text { SD1 }\end{array}$ & $\begin{array}{l}6 \\
6 \\
5 \\
4 \\
6 \\
4 \\
6 \\
5 \\
6 \\
4\end{array}$ & $\begin{array}{l}46 \\
42 \\
52 \\
44 \\
35 \\
52 \\
38 \\
36 \\
30 \\
31\end{array}$ & $\begin{array}{c}4 \\
(1) \\
4 \\
(2) \\
13 \\
12 \\
9 \\
36 \\
36\end{array}$ & $\begin{array}{l}26 \\
22 \\
19 \\
18 \\
13 \\
22 \\
19 \\
20 \\
33 \\
33\end{array}$ & $\begin{array}{l}24 \\
35 \\
25 \\
37 \\
25 \\
26 \\
27 \\
30 \\
- \\
-\end{array}$ & $\begin{array}{l}- \\
\overline{-} \\
\overline{14} \\
\frac{5}{4} \\
-\end{array}$ \\
\hline
\end{tabular}

All figures are expressed as a percentage of the total monosaccharide found in the unfractionated protein and are arithmetic means of the results of the individual analyses. The standard deviation of the readings was 1.78 with $183 \mathrm{~d} . \mathrm{f}$

UD1, etc. = urinary protein from workman D1, etc.

SD1 = serum protein from workman D1.

UN1 and UN2 = urinary protein from two nephritic patients.

$=$ normal serum protein.

HIP was prepared from UD1.

TABLE 3

HEXOSE CONTENT OF ELECTROPHORETICALLY SEPARATED COMPONENTS OF CADMIUM URINARY PROTEINS AND NEPHRITIC URINARY AND NORMAL SERUM PROTEINS

\begin{tabular}{|c|c|c|c|c|c|c|c|}
\hline \multirow{2}{*}{ Nature of Protein } & \multirow{2}{*}{ Total Protein } & \multicolumn{4}{|c|}{ Component } & \multirow{2}{*}{ HIP } & \multirow{2}{*}{ HCP } \\
\hline & & 1 & 2 & 3 & 4 & & \\
\hline $\begin{array}{l}\text { UD1 } \\
\text { UD2 } \\
\text { UF1 } \\
\text { UF2 } \\
\text { UF3 } \\
\text { UN1 } \\
\text { UN2 } \\
\text { SN } \\
\text { SD1 }\end{array}$ & $\begin{array}{l}76 \\
98 \\
86 \\
67 \\
86 \\
31 \\
33 \\
17 \\
19\end{array}$ & $\begin{array}{r}58 \\
94 \\
85 \\
65 \\
52 \\
14 \\
12 \\
7 \\
6\end{array}$ & $\begin{array}{l}77 \\
84 \\
89 \\
82 \\
59 \\
31 \\
- \\
-\end{array}$ & $\begin{array}{l}29 \\
32 \\
41 \\
36 \\
42 \\
22 \\
24 \\
17 \\
18\end{array}$ & $\begin{array}{r}14 \\
8 \\
10 \\
12 \\
18 \\
12 \\
13 \\
7 \\
8\end{array}$ & $\begin{array}{l}139 \\
147 \\
136 \\
129 \\
138 \\
= \\
- \\
-\end{array}$ & $\begin{array}{l}11 \\
10 \\
13 \\
9 \\
12 \\
= \\
= \\
-\end{array}$ \\
\hline
\end{tabular}

The hexose values were determined by reference to a galactose: mannose $(2: 1)$ standard and are expressed as mg./g. protein (biuret). Each figure is the mean of two readings.

HIP and HCP = heat incoagulable and heat coagulable fractions of component 1 . Other symbols are as in Table 2. 
TABLE 4

SIALIC ACID CONTENT OF ELECTROPHORETICALLY SEPARATED PROTEIN COMPONENTS OF CADMIUM WORKMEN AND NEPHRITIC PATIENTS

\begin{tabular}{|c|c|c|c|c|c|c|c|}
\hline \multirow{2}{*}{ Nature of Protein } & \multirow{2}{*}{ Total Protein } & \multicolumn{4}{|c|}{ Component } & \multirow{2}{*}{ HIP } & \multirow{2}{*}{ HCP } \\
\hline & & 1 & 2 & 3 & 4 & & \\
\hline $\begin{array}{l}\text { UD1 } \\
\text { UD2 } \\
\text { UF1 } \\
\text { UF2 } \\
\text { UF3 } \\
\text { UN1 } \\
\text { UN2 } \\
\text { SN } \\
\text { SD1 }\end{array}$ & $\begin{array}{r}31 \\
40 \\
31 \\
37 \\
33 \\
20 \\
22 \\
9 \\
10\end{array}$ & $\begin{array}{r}28 \\
38 \\
27 \\
33 \\
31 \\
11 \\
12 \\
4 \\
4\end{array}$ & $\begin{array}{l}23 \\
31 \\
26 \\
30 \\
24 \\
17 \\
- \\
-\end{array}$ & $\begin{array}{r}9 \\
15 \\
12 \\
14 \\
10 \\
7 \\
9 \\
5 \\
6\end{array}$ & $\begin{array}{l}3 \\
2 \\
4 \\
4 \\
5 \\
3 \\
4 \\
2 \\
2\end{array}$ & $\begin{array}{l}61 \\
65 \\
57 \\
69 \\
70 \\
- \\
- \\
-\end{array}$ & $\begin{array}{r}6 \\
6 \\
4 \\
4 \\
5 \\
- \\
-\end{array}$ \\
\hline
\end{tabular}

The hexose values ware determined by reference to a galactose: mannose $(2: 1)$ standard and are expressed as mg./g. protein (biuret). Each figure is the mean of two readings.

HIP and HCP $=$ heat incoagulable and heat coagulable fractions of component 1 . Other symbols are as in Table 2

TABLE 5

METHYLPENTOSE CONTENT OF ELECTROPHORETICALLY SEPARATED COMPONENTS OF CADMIUM URINARY PROTEINS AND NEPHRITIC URINARY AND NORMAL SERUM PROTEINS

\begin{tabular}{|c|c|c|c|c|c|c|c|}
\hline \multirow{2}{*}{ Nature of Protein } & \multirow{2}{*}{ Total Protein } & \multicolumn{4}{|c|}{ Component } & \multirow{2}{*}{ HIP } & \multirow{2}{*}{ HCP } \\
\hline & & 1 & 2 & 3 & 4 & & \\
\hline $\begin{array}{l}\text { UD1 } \\
\text { UD2 } \\
\text { UF1 } \\
\text { UF2 } \\
\text { UF3 } \\
\text { UN1 } \\
\text { UN2 } \\
\text { SN }\end{array}$ & $\begin{array}{c}16 \\
18 \\
15 \\
17 \\
15 \\
5.3 \\
6.1 \\
1.1\end{array}$ & $\begin{array}{c}14 \\
17 \\
16 \\
16 \\
14 \\
2 \cdot 1 \\
2.0 \\
0 \cdot 3\end{array}$ & $\begin{array}{c}19 \\
20 \\
20 \\
19 \\
15 \\
4.8 \\
-\end{array}$ & $\begin{array}{l}6 \\
5 \\
6 \\
6 \\
7 \\
3 \cdot 7 \\
3 \cdot 9 \\
1 \cdot 2\end{array}$ & $\begin{array}{l}2 \\
2 \\
3 \\
3 \\
3 \\
1.9 \\
1.7 \\
0.4\end{array}$ & $\begin{array}{l}31 \\
29 \\
31 \\
29 \\
27 \\
- \\
-\end{array}$ & $\begin{array}{l}2 \\
2 \\
2 \\
2 \\
2 \\
- \\
-\end{array}$ \\
\hline
\end{tabular}

The hexose values were determined by reference to a galactose: mannose $(2: 1)$ standard and are expressed as mg./g. protein (biuret). Each figure is the mean of two readings.

HIP and HCP ... heat incoagulable and heat coagulable fractions of component 1 . Other symbols are as in Table 2.

examined in the ultracentrifuge. The slower of these two components appeared to sediment at about the same rate as the whole urinary protein, but the resolution of the two peaks was inadequate to permit the calculation of sedimentation coefficients.

Immunology.-Preliminary investigations of the complete cadmium urinary protein analysed by the precipitin test in agar gel tubes against rabbit antiserum to all normal human serum proteins showed a very complex immunological behaviour. Both serum and nephritic urinary protein also gave a multiplicity of bands but HIP (D1) produced only two major bands. Using smaller tubes $(0.2 \mathrm{~cm}$. in diameter) the electrophoretic components from cadmium urinary and serum protein were also tested. In each case only one band was detected. The use of the smaller tubes, employed because of the small quantities of components available, reduced the sensitivity of the technique.

Immunoelectrophoresis.-The pattern of precipitin curves developed after immunoelectrophoresis by the total urinary protein of patient F3 was compared on the same agar gel plate with that of normal human plasma, using a rabbit antiserum against whole human plasma. Six discrete pre- cipitin bands were formed by the cadmium urinary protein, and these spread over the mobility range of albumin to $\gamma$-globulin of normal human plasma.

The investigation was not a quantitative one and it is impossible to exclude the possibility that the precipitin bands arose from the presence of serum proteins in the urine in such low concentrations as to be undetected by the ultracentrifuge.

Viscosity.-Total urinary protein from each of the five cadmium workmen was dissolved in isotonic saline and centrifuged free of undissolved protein. Relative viscosities were calculated for solutions containing $5.0 \mathrm{~g} . / 100 \mathrm{ml}$. of dissolved protein, the approximate concentration of the solutions employed. The results are shown in Table 7.

Reducing Sugars.-Each urine sample was tested for reducing sugar with Benedict's reagent. UD1, UF1, UF2 and UF3 persistently showed a trace of reducing sugar, UD2 intermittently, and observations with glucose oxidase ("clinistix") were consistent with the assumption that glucose was responsible. The quantity of glucose present was uniformly less than $0 \cdot 1 \mathrm{~g} . / 100 \mathrm{ml}$. urine.

Tests for ketone compounds, haemoglobin, and microscopic examination of centrifuged urinary 
deposits for crystalline deposits, cells, and casts were consistently negative.

\section{Discussion}

From the electrophoretic studies of the biocolloids present in the urine of 11 normal male subjects, Webb et al. (1958a) have computed that 24-hour samples of normal urine contained on an average $133 \mathrm{mg}$. protein. At least seven components were revealed, five of which were similar in electrophoretic mobility to the principal five fractions in serum. A relatively large quantity of protein was present, rich in carbohydrate, which behaved similarly to acid muco-proteins of normal serum. No lipoproteins were detected. Following injection
TABLE 7

RELATIVE VISCOSITIES OF URINARY PROTEINS OF CADMIUM WORKERS

\begin{tabular}{cc}
\hline Source & Relative Viscosity \\
\hline UD1 & 1.24 \\
UD2 & 1.26 \\
UF1 & 1.25 \\
UF2 & 1.26 \\
UF3 & 1.26 \\
\hline
\end{tabular}

Relative viscosity is measured in terms of water $=1.00$ and was determined on solutions containing $5.0 \mathrm{~g}$. protein $/ 100 \mathrm{ml} .0 \cdot 9 \% \mathrm{NaCl}$.

of $I^{131}$-tagged human serum $\gamma_{2}$-globulins into normal volunteers the iodinated material in the urine exhibited an electrophoretic distribution very similar to that in the serum. The fact that this

TABLE 6 AMINO ACID COMPOSITION OF ELECTROPHORETIC COMPONENTS OF SERUM AND URINARY PROTEINS FROM CADMIUM WORKERS AND NEPHRITIC PATIENTS

\begin{tabular}{|c|c|c|c|c|c|c|c|c|c|c|}
\hline $\begin{array}{l}\text { Original } \\
\text { Protein }\end{array}$ & $\begin{array}{c}\text { No. of } \\
\text { Analyses }\end{array}$ & Component & Arginine & Lysine & Aspartic Acid & Glutamic Acid & Histidine & Glycine & Serine & Alanine \\
\hline $\begin{array}{l}\text { UD1 } \\
\text { UD2 } \\
\text { UF1 } \\
\text { UF2 } \\
\text { UF3 } \\
\text { UN1 } \\
\text { UN2 } \\
\text { SN } \\
\text { SD1 } \\
\text { Albumin* }\end{array}$ & $\begin{array}{l}4 \\
4 \\
2 \\
2 \\
7 \\
3 \\
2 \\
2 \\
3 \\
-\end{array}$ & $\begin{array}{l}1 \\
1 \\
1 \\
1 \\
1 \\
1 \\
1 \\
1\end{array}$ & $\begin{array}{l}8 \cdot 4 \\
8 \cdot 1 \\
8 \cdot 4 \\
8 \cdot 6 \\
8 \cdot 0 \\
8 \cdot 7 \\
7 \cdot 1 \\
8 \cdot 4 \\
8 \cdot 1 \\
8\end{array}$ & $\begin{array}{l}11.7 \\
12.1 \\
13.4 \\
13.3 \\
12.3 \\
14.6 \\
12.1 \\
14.7 \\
14.4 \\
17\end{array}$ & $\begin{array}{l}18.9 \\
16 \cdot 2 \\
16 \cdot 2 \\
20.9 \\
16 \cdot 6 \\
18 \cdot 3 \\
17.9 \\
16 \cdot 1 \\
17.2 \\
16\end{array}$ & $\begin{array}{l}20 \cdot 9 \\
21 \cdot 3 \\
23 \cdot 1 \\
23 \cdot 6 \\
22 \cdot 4 \\
24 \cdot 4 \\
24 \cdot 5 \\
26 \cdot 8 \\
24 \cdot 6 \\
24\end{array}$ & $\begin{array}{l}2 \cdot 6 \\
2 \cdot 8 \\
2 \cdot 6 \\
2 \cdot 8 \\
2 \cdot 1 \\
2 \cdot 1 \\
3 \cdot 0 \\
3 \cdot 3 \\
2 \cdot 5 \\
4\end{array}$ & $\begin{aligned} 9 \cdot 1 \\
10 \cdot 3 \\
8 \cdot 2 \\
6 \cdot 4 \\
9 \cdot 1 \\
7 \cdot 1 \\
6 \cdot 1 \\
4 \cdot 3 \\
4 \cdot 7 \\
4\end{aligned}$ & $\begin{array}{r}10.3 \\
12.2 \\
11.2 \\
9.0 \\
11.9 \\
8.5 \\
7.4 \\
6.5 \\
7.6 \\
7\end{array}$ & $\begin{array}{l}18.1 \\
17.0 \\
16.9 \\
15.4 \\
17.5 \\
16.4 \\
21.7 \\
19.8 \\
21.4 \\
(20)\end{array}$ \\
\hline $\begin{array}{l}\text { UD1 } \\
\text { UD2 } \\
\text { UF1 } \\
\text { UF2 } \\
\text { UF3 } \\
\text { UN1 } \\
\text { x-globulin* }\end{array}$ & $\begin{array}{l}3 \\
3 \\
2 \\
2 \\
2 \\
2 \\
\end{array}$ & $\begin{array}{l}2 \\
2 \\
2 \\
2 \\
2 \\
2 \\
\end{array}$ & $\begin{array}{c}9 \cdot 5 \\
7 \cdot 9 \\
10 \cdot 3 \\
9 \cdot 6 \\
9.0 \\
10 \cdot 8 \\
7\end{array}$ & $\begin{array}{r}7 \cdot 5 \\
9.9 \\
9 \cdot 3 \\
8 \cdot 9 \\
11 \cdot 7 \\
8 \cdot 8 \\
13\end{array}$ & $\begin{array}{l}20 \cdot 7 \\
17 \cdot 8 \\
21.4 \\
19.9 \\
19 \cdot 3 \\
22 \cdot 3 \\
15\end{array}$ & $\begin{array}{l}17 \cdot 7 \\
18 \cdot 8 \\
18 \cdot 5 \\
18 \cdot 6 \\
18 \cdot 0 \\
17 \cdot 7 \\
31\end{array}$ & $\begin{array}{l}2 \cdot 4 \\
2 \cdot 4 \\
2 \cdot 3 \\
2 \cdot 7 \\
2 \cdot 3 \\
3 \cdot 1 \\
4\end{array}$ & $\begin{array}{c}13.7 \\
14.2 \\
11.3 \\
13.0 \\
13.1 \\
14.2 \\
9\end{array}$ & $\begin{array}{l}13.5 \\
14.4 \\
12.7 \\
13.1 \\
13.8 \\
10.9 \\
10\end{array}$ & $\begin{array}{l}15.0 \\
14.8 \\
14.2 \\
14.2 \\
11.9 \\
12.2 \\
(12)\end{array}$ \\
\hline $\begin{array}{l}\text { UD1 } \\
\text { UD2 } \\
\text { UF1 } \\
\text { UF2 } \\
\text { UF3 } \\
\text { UN1 } \\
\text { UN2 } \\
\text { SN } \\
\text { SD1 } \\
\beta \text {-globulin }\end{array}$ & $\begin{array}{l}2 \\
3 \\
2 \\
2 \\
2 \\
2 \\
3 \\
3 \\
2 \\
2 \\
-\end{array}$ & $\begin{array}{l}3 \\
3 \\
3 \\
3 \\
3 \\
3 \\
3 \\
3 \\
\mathbf{3} \\
\end{array}$ & $\begin{array}{r}7.8 \\
9.9 \\
9 \cdot 7 \\
8 \cdot 9 \\
10 \cdot 9 \\
9 \cdot 0 \\
9 \cdot 1 \\
9 \cdot 3 \\
9 \cdot 5 \\
6\end{array}$ & $\begin{array}{r}8.0 \\
10.9 \\
10 \cdot 6 \\
10.2 \\
10.3 \\
10.4 \\
8.5 \\
10.4 \\
10.8 \\
10\end{array}$ & $\begin{array}{l}16 \cdot 1 \\
16 \cdot 5 \\
16 \cdot 7 \\
17 \cdot 4 \\
17 \cdot 1 \\
18 \cdot 1 \\
17 \cdot 3 \\
17.8 \\
19 \cdot 4 \\
16\end{array}$ & $\begin{array}{l}18.2 \\
18.9 \\
18 \cdot 3 \\
17.4 \\
17.2 \\
17.2 \\
20 \cdot 4 \\
16.9 \\
20 \cdot 0 \\
21\end{array}$ & $\begin{array}{l}2 \cdot 6 \\
2 \cdot 8 \\
2 \cdot 2 \\
2 \cdot 9 \\
2 \cdot 9 \\
2 \cdot 3 \\
2 \cdot 1 \\
2 \cdot 6 \\
2 \cdot 0 \\
4\end{array}$ & $\begin{array}{l}13.9 \\
12.4 \\
13.7 \\
14.0 \\
12.0 \\
12.1 \\
12.0 \\
13.2 \\
12.4 \\
16\end{array}$ & $\begin{array}{l}15.7 \\
16.9 \\
15.1 \\
15.5 \\
15.8 \\
18.4 \\
13.2 \\
18.1 \\
13.5 \\
15\end{array}$ & $\begin{array}{l}17.7 \\
11.6 \\
13.7 \\
13.7 \\
13.8 \\
12.4 \\
17.4 \\
11.6 \\
12.4 \\
(12)\end{array}$ \\
\hline $\begin{array}{l}\text { UD1 } \\
\text { UD2 } \\
\text { UF1 } \\
\text { UF2 } \\
\text { UF3 } \\
\text { UN1 } \\
\text { UN2 } \\
\text { SN } \\
\text { SDI } \\
\gamma \text {-globulin }\end{array}$ & $\begin{array}{l}3 \\
2 \\
2 \\
3 \\
2 \\
2 \\
2 \\
2 \\
3 \\
-\end{array}$ & $\begin{array}{l}4 \\
4 \\
4 \\
4 \\
4 \\
4 \\
4 \\
4 \\
4 \\
\end{array}$ & $\begin{array}{r}6 \cdot 2 \\
7 \cdot 7 \\
7 \cdot 6 \\
7 \cdot 5 \\
8 \cdot 5 \\
8 \cdot 6 \\
9.9 \\
10 \cdot 0 \\
9.9 \\
4\end{array}$ & $\begin{array}{r}6 \cdot 3 \\
7 \cdot 5 \\
7 \cdot 7 \\
9 \cdot 7 \\
10 \cdot 5 \\
9 \cdot 1 \\
8 \cdot 6 \\
8 \cdot 6 \\
10 \cdot 4 \\
12\end{array}$ & $\begin{array}{l}13.9 \\
12.5 \\
13.6 \\
14.5 \\
14.0 \\
14.0 \\
14.3 \\
13.3 \\
15.7 \\
14\end{array}$ & $\begin{array}{l}18.6 \\
18.9 \\
18.6 \\
17.4 \\
16.6 \\
17.9 \\
22.9 \\
18.8 \\
18.3 \\
17\end{array}$ & $\begin{array}{l}2 \cdot 2 \\
2 \cdot 1 \\
2 \cdot 0 \\
2 \cdot 8 \\
1.9 \\
2 \cdot 3 \\
2 \cdot 0 \\
3.9 \\
3 \cdot 0 \\
4\end{array}$ & $\begin{array}{l}14 \cdot 7 \\
12 \cdot 9 \\
13 \cdot 1 \\
13 \cdot 1 \\
13 \cdot 8 \\
16 \cdot 1 \\
14 \cdot 0 \\
12.7 \\
12.5 \\
12\end{array}$ & $\begin{array}{l}20.7 \\
21.4 \\
20.8 \\
18.2 \\
22.2 \\
16.7 \\
14.5 \\
19.4 \\
17.9 \\
23\end{array}$ & $\begin{array}{l}17.4 \\
17.0 \\
16.6 \\
16.9 \\
12.5 \\
15.3 \\
11.2 \\
13.1 \\
13.7 \\
(13)\end{array}$ \\
\hline $\begin{array}{l}\text { UD1 } \\
\text { UD2 } \\
\text { UF1 } \\
\text { UF2 } \\
\text { UF3 } \\
\text { UD2 } \\
\text { UF1 } \\
\text { UF2 } \\
\text { UF3 } \\
\text { Error† } \\
\text { Variance }\end{array}$ & $\begin{array}{l}2 \\
2 \\
2 \\
2 \\
2 \\
4 \\
2 \\
2 \\
2 \\
\\
-\end{array}$ & $\begin{array}{l}\text { HIP } \\
\text { HIP } \\
\text { HIP } \\
\text { HIP } \\
\text { HIP } \\
\text { HCP } \\
\text { HCP } \\
\text { HCP } \\
\text { HCP } \\
-\end{array}$ & $\begin{array}{c}8.5 \\
8.4 \\
8.1 \\
8.9 \\
10.7 \\
11.4 \\
9.9 \\
10.1 \\
12.3 \\
0.73 \\
0.45\end{array}$ & $\begin{array}{c}11.2 \\
10.8 \\
10.3 \\
9 \cdot 2 \\
9.5 \\
17.2 \\
15.3 \\
15.2 \\
13.4 \\
0.79 \\
0.65\end{array}$ & $\begin{array}{c}18.0 \\
18.9 \\
17.1 \\
18.7 \\
19.4 \\
18.6 \\
17.9 \\
19.2 \\
20.4 \\
1.44 \\
1.71\end{array}$ & $\begin{array}{c}19.4 \\
21.5 \\
24.3 \\
24.5 \\
25.6 \\
22.2 \\
22.7 \\
22.0 \\
25.4 \\
1.47 \\
1.98\end{array}$ & $\begin{array}{l}2 \cdot 6 \\
2 \cdot 6 \\
3 \cdot 1 \\
2 \cdot 4 \\
2 \cdot 6 \\
2 \cdot 3 \\
4 \cdot 3 \\
3 \cdot 1 \\
1 \cdot 2 \\
0.56 \\
0.18\end{array}$ & $\begin{array}{c}12.9 \\
11.2 \\
13.9 \\
12.9 \\
10.2 \\
4.5 \\
4.6 \\
4.9 \\
5.0 \\
1.10 \\
1.15\end{array}$ & $\begin{array}{l}13.0 \\
14.1 \\
10.9 \\
11.2 \\
9.9 \\
7.3 \\
7.0 \\
7.4 \\
7.2 \\
1.25 \\
1.55\end{array}$ & $\begin{array}{c}14 \cdot 4 \\
12 \cdot 2 \\
12.4 \\
12.4 \\
12.0 \\
16 \cdot 6 \\
18.5 \\
18 \cdot 2 \\
15 \cdot 1 \\
1.28 \\
1.42\end{array}$ \\
\hline
\end{tabular}

The values represent the individual amino acids expressed as a percentage of the total of the eight measured in terms of $x$-amino nitrogen. Symbols for the protein sources as in Table 2 but HIP and HCP prepared from component 1 .

* Data on the normal human serum proteins by ion exchange chromatography (Moore and Stein, 1949).

$\dagger$ Mean difference between 42 pairs of duplicate readings. 
urinary globulin had approximately the same relative specific activity as the corresponding serum $\gamma_{2}$-globulin was taken to indicate that the urinary component was closely related in its formation to the corresponding serum fraction, whilst the other proteins in the urine which were not labelled with $\mathbf{I}^{\mathbf{1 3 1}}$ were not derived from $\gamma$-globulins.

Physico-chemical studies (Webb et al., 1958b) have failed to distinguish between serum albumin and the albumin fraction of normal urine, but urinary $\gamma_{2}$-globulins are molecules of relatively low molecular weight, 10,600. Rowe (1957) has also observed that urinary albumin of nephritic individuals is identical with the serum albumin of the same individual and with normal serum albumin by immunochemical and osmotic criteria. The average molecular weights calculated for the globulins found in nephrotic urine were invariably less than those of serum albumin and ranged between 36,000 and 65,000 .

In the present study of the proteinuria of cadmium workers the quantity of protein excreted was 1.0-3.2 g./1., much in excess of normal. There is a preponderance of low molecular weight proteins in all the fractions into which it can be separated electrophoretically, it being impossible to exclude on the basis of immunological and ultracentrifugal data the presence of traces of normal serum proteins.

The low sedimentation coefficient on ultracentrifugation indicated a uniformly low molecular weight of 20,000-30,000 for all the protein components.

Electrophoretic analysis on paper showed a definite preponderance of urinary globulins, especially $\alpha_{2}$-globulin, over urinary albumin (Fig. 1a), much of which could be ascribed to the presence of a heat incoagulable protein migrating in that region (Fig. 1b). Column electrophoresis on acetyl cellulose revealed a relatively higher proportion of urinary albumin, possibly due to a more rapid migration of the heat incoagulable protein in the borate-phosphate buffer (Fig. 2i, j). The hexose, sialic acid, and methylpentose contents of HIP were much higher than for any other protein fraction observed in urine or serum (Tables 3,4 , and 5), whilst corresponding values for urinary albumin were greatly in excess of those found in serum albumin. Fraction 2 of urinary protein from the cadmium workers also contained far more bound carbohydrate than did the urinary protein of nephritic patients. It is probable, therefore, that the urinary albumin fraction was augmented on the acetyl cellulose column by admixture with the heat incoagulable protein, and, indeed, some evidence of two components became apparent on ultracentrifugation.

Amino acid analyses showed that fraction 1 (urinary albumin) was strikingly higher in its content of glycine and serine than serum albumin and, again, a similar difference was seen in the composition of the heat incoagulable protein. Otherwise, no significant differences were apparent between the amino acid composition of corresponding protein fractions separated by column electrophoresis from normal serum, workers' serum, and urine of nephritic patients.

The peculiarity of cadmium proteinuria rests, therefore, upon a preponderance of low molecular weight proteins, some of which are of high carbohydrate content. In contrast to the proteins observed in the urine of normal individuals, of nephritic, as well as of nephrotic patients, fraction 1 (urinary albumin) of cadmium workers is readily distinguishable from serum albumin by its low molecular weight, 20-30,000, whilst the $\gamma$ fraction, of similar molecular size to this, exceeds that of normal urinary $\gamma_{2}$-globulin, 10,600 . It is not known whether the protein originates from the plasma although we have obtained evidence (Wells, Smith, and Kench, unpublished) from studies of incorporation of $\mathrm{C}^{14}$ labelled glycine and lysine into the proteins of serum and urine that this may obtain in cadmium poisoned rabbits. It is hoped that by further such studies the site of biochemical action of cadmium may be located.

For a most valuable part of this study we are indebted to Dr. R. A. Kekwick who carried out the ultracentrifugal and immuno-electrophoretic experiments recorded above.

The authors also wish to express their gratitude to Miss I. Dingwall-Fordyce for all her help with statistical aspects of the work. Generous advice and encouragement has been received from Professor R. E. Lane, C.B.E. whose interest in chronic cadmium poisoning prompted this study. We should like to thank Professor A. C. P. Campbell for his support during the later stages of this work. Our thanks are also due to Drs. D. E. Aspin, C. L. Potts, and D. F. S. Flood for allowing us access to the men under their care. The Medical Research Council have generously supported these studies with grants to J.C.S. and A.R.W.

\section{REFERENCES}

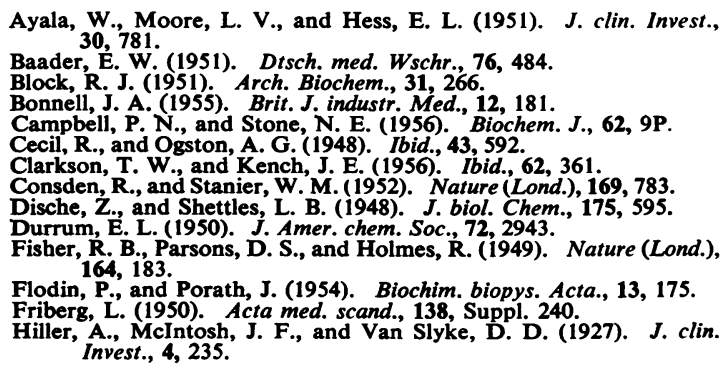


Jermyn, M. A., and Isherwood, F. A. (1949). Biochem. J., 44, 402. Kekwick, R. A. (1955). Brit. J. industr. Med., 12, 196.

(1958). Personal communication.

McGarry, E., Sehon, A. H., and Rose, B. (1955). J. clin. Invest., 34, 832.

Moore, S., and Stein, W. H. (1949). J. biol. Chem., 178, 53.

Oakley, C. L., and Fulthorpe, A. J. (1953). J. Path. Bact., 65, 49.

Owen, J. A., Iggo, B., Scandrett, F. J., and Stewart, C. P. (1954) Biochem. J., 58, 426

Partridge, S. M. (1048). Ibid., 43, 238.

Philpot, J.St.L. (1938). Nature (Lond.), 141, 283.

Plückthun, H., and Götting, H. (1951). Klin. Wschr., 29, 415.

Rowe, D. S. (1957). Biochem. J., 67, 435

Smith, J. C., and Kench, J. E. (1957), Brit. J. industr. Med., 14, 240.

Smith, J. C., and Kench, J. E. (1957). Brit. J. industr. Med.

Webb, T., Rose, B., and Sehon, A. H. (1958a). Canad. J. Biochem. 36, 1159.

$\longrightarrow$ (1958b). Ibid., 36, 1167.

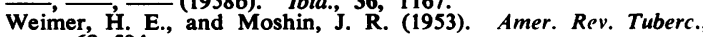
$68,594$.

\section{THE OCTOBER (1960) ISSUE}

The October (1960) issue contains the following papers:-

The Relation between Lung Dust and Lung Pathology in Pneumoconiosis. By G. Nagelschmidt.

Diffuse Pleural Mesothelioma and Asbestos Exposure in the North Western Cape Province. By J. C. Wagner, C. A. Sleggs, and Paul Marchand.

Dust Diseases in Dundee Textile Workers. By A. Mair, D. H. Smith, W. A. Wilson, and W. Lockhart.

The Study of Observer Variation in the Radiological Classification of Pneumoconiosis. By J. W. J. Fay and J. R. Ashford.

The Classification of Chest Radiographs for Coalworkers' Pneumoconiosis. By J. R. Ashford.

The Relationship of Byssinosis in the Bacteria and Fungi in the Air of Textile Mills. By Peter Tuffnell.

Experimental Byssinosis. By Peter Tuffnell.

Sickness Absence Among Forestry Workers in the North of Scotland, 1958. By Donald McGregor.

Ecological Factors Affecting Efficiency and Health in Warships. By F. P. Ellis.

Book Reviews.

Index.

A number of copies are still available and may be obtained from the Publishing Manager, British Medical Association, Tavistock Square, W.C.1, price 17s. 6 d. 